\title{
How to prevent the cuff pressure increasing during inhalation anesthesia?
}

\section{麻酔中における気管内チューブのカフ内圧上昇の原因とその対策について}

\author{
Shinya HASEGAWA, Manabu KAWABE, Haruna YUZA, Hirotoshi SATO, Masato SHIMADA, \\ Yoshihiro MIZUNO and Yoshio KINEFUCHI
}

Dept. of Biomedical Engineering, School of High-Technology for Human Welfare, Tokai University, 317 Nishino, Numazu, Shizuoka, 410-0321, Japan

TEL: 81-55-968-1111(EX.4418)

( Received 26, January 2004 Accepted 1, April 2004 )

\begin{abstract}
The relationships between the pressure in the tracheal tube cuff with the components of inflation gases and inhalation gases were examined by the simulation technique based on the gas transmission theory. We demonstrated that nitrous oxide gas in the inhalation gases transmitted in through cuff material so as to increase the cuff pressure, whereas carbon dioxide gas in the inflation gases moved out through cuff material and exerted to decrease the cuff pressure. These results show that a certain amount of carbon dioxide gas may compensate the transmission of nitrous oxide gas and keep the cuff pressure constant during nitrous oxide anesthesia.
\end{abstract}

Keywords : Cuff, Endotracheal tube, Nitrous oxide $\left(\mathrm{N}_{2} \mathrm{O}\right)$

\section{INTRODUCTION}

吸入麻酔中、気管内チューブのカフ内(Fig.1)に麻酔ガ スの笑気が進入し、内圧が上昇していく現象が起こる。 過度のカフ内圧上昇は気管粘膜の灌流障害を起こし、術 後の嗄声や喉頭痛の原因となる。カフを正常の圧

$(5 \mathrm{cmHg})$ で 6 時間膨らませた時、線毛の回復に要する 時間は 3 日以内だが、 $15 \mathrm{cmHg}$ の場合回復に $8 \sim 14$ 日か かってしまう。線毛細胞は気道を浄化する作用をもち、 これがカフ内圧の上昇により損なわれ、回復に 8 日以上 も要することは臨床的に見て重要な問題を含んでいる。 ${ }^{1}$

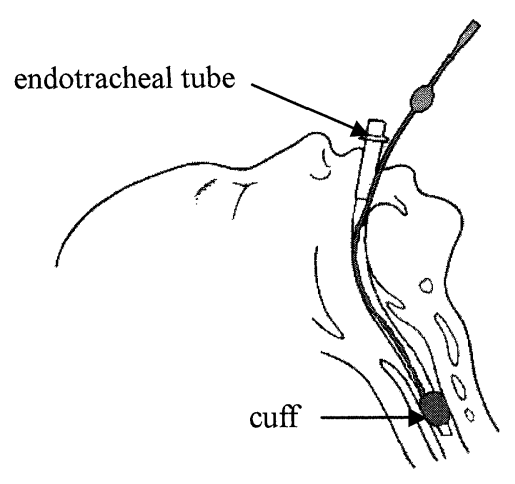

Fig.1.Endotracheal intubation.
カフ内への笑気の進入は膜内外の分圧差によって生ず る。このような高分子膜を介しての気体分子の移動、圧 変化をシミュレーションによって可視化することは現象 の理解を容易にするとともに、気体透過性の低い膜素材 の開発や、カフ構造の検討に有力な手段を提供する。

本稿ではシミュレーションによって膜内外の気体移動 を明示しながら、混合気体を用いたカフ内圧の上昇を防 止しうる混合気体の使用の可能性について検討した。

\section{EXPERIMENTAL}

高分子膜を介した気体透過量は、気体透過量 $=($ 気体透 過係数 $\times$ 圧力差 $\times$ 面積 $\times$ 時間 $) （$ (膜の厚さ) で与えられ る。

Fig.2 に示すように、カフの半分は空気（口側）、他は 笑気・酸素の混合気（肺側）に曝される。カフ膜のガス 透過係数を $\mathrm{Q}$ 、カフの表面積を $\mathrm{A}$ 、カフ膜の厚さを $\mathrm{L}$ 、 カフ膜内外の分圧差を $\Delta \mathrm{p}$ とすると単位時間内に膜を通 過するガス量 q は、

$\mathrm{q}=\mathrm{Q} \cdot \mathrm{A} \cdot \Delta \mathrm{p} / \mathrm{L}$

で表される。あるガスについて、カフ内分圧を $\mathrm{P}_{\mathrm{c}}$ 、口側 分圧を $\mathrm{P}_{\mathrm{m}}$ 、口側のカフ表面積を $\mathrm{A}_{\mathrm{m}}$ で表すと、口側から カフ内への透過量 $\Delta \mathrm{q}$ は

$\Delta \mathrm{q}=\mathrm{QA}_{\mathrm{m}}\left(\mathrm{P}_{\mathrm{m}}-\mathrm{P}_{\mathrm{c}}\right) / \mathrm{L}$

で表される。カフ体積を V とし、移行したガス量による 
カフ内圧の変化を $\Delta \mathrm{P}_{\mathrm{c}}$ とすれば、

$$
\Delta \mathrm{P}_{\mathrm{c}} \cdot \mathrm{V}=\mathrm{K} \cdot \Delta \mathrm{q}=\mathrm{K}^{\prime}\left(\mathrm{P}_{\mathrm{m}}-\mathrm{P}_{\mathrm{c}}\right)
$$

となる。これは $\mathrm{Pc}$ について、

$$
\mathrm{dP} / \mathrm{dt}+\mathrm{K} " \mathrm{P}_{\mathrm{c}}=\mathrm{K} ",
$$

となり、 K”、K”"を初期值とする 1 次微分方程式で表さ れる。この式から $\mathrm{P}_{\mathrm{c}}$ の時間変化を知ることができる。構 成するガスの分圧の和がカフ内圧となる。

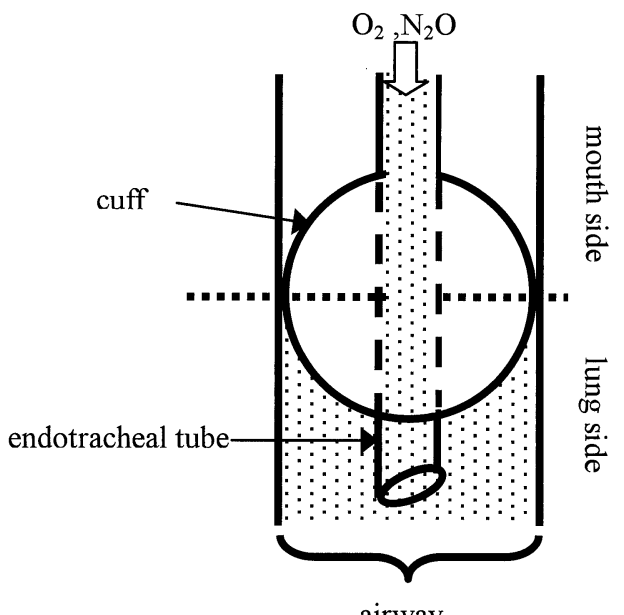

Fig.2. Trachea with endotracheal cuff.

例えば大気圧を $76 \mathrm{cmHg}$ 、初期カフ内圧を $3 \mathrm{cmHg}$ とし、 麻酔ガスを笑気 : 酸素 $=1: 1$ の気体、カフを膨らませる 気体を空気、肺胞気炭酸ガス分圧 $4 \mathrm{cmHg}$ としたときのカ フ内、口側、肺側の分圧分布を Fig.3 に示す。

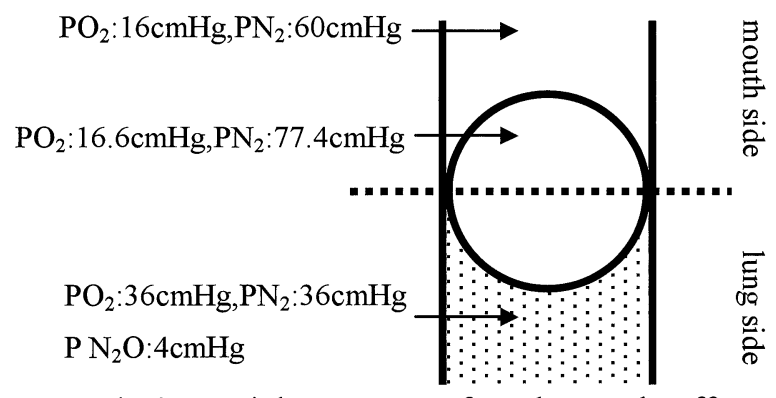

Fig.3. Partial pressures of trachea and cuff.

上式をプログラムし(Microsoft@ Visual Basic®6.0を使 用)、初期条件を変えたときのカフ内圧の変化を観察した。

Fig.4 に設定画面を示す。大気圧、カフを膨張させる気 体の構成（空気、その他）、初期カフ内圧、カフの材質、 膜厚、表面積、サンプリング間隔、表示形式（絶対圧、 分圧）等を設定する。またシミュレーションしたデータ を csv 形式で保存できるようにした。

作成したシミュレーションソフトでカフを膨らませる 気体の種類、圧を変えてシミュレーションし、空気で膨 らませた場合と比較することにした。
気管内チューブの次元の算出には PORTEX® \#8 を用 いた。チューブ内径は $8 \mathrm{~mm}$ 、カフ材料は PVC、膜厚は $0.025 \mathrm{~cm}$ 、表面積は $4 \mathrm{~cm}^{2}$ 、カフ体積は $8 \mathrm{ml}$ である。

PVC の $25^{\circ} \mathrm{C}$ におけるガス透過係数を Table 1 に示す。

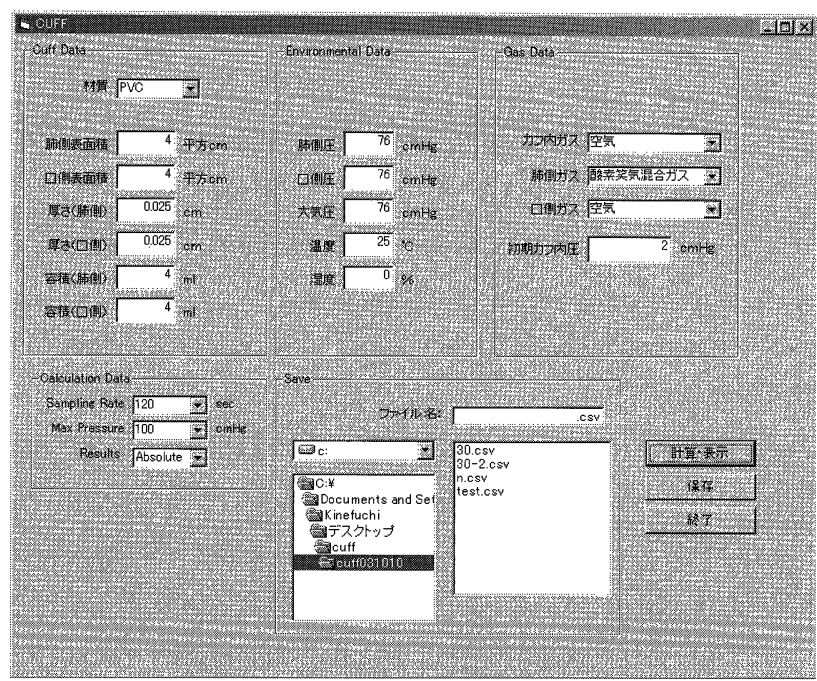

Fig.4. Setting window.

Table 1.Gas transmission rate of PVC. ${ }^{2}$ $\left[25^{\circ} \mathrm{C}, 10^{-8}\left(\mathrm{~cm}^{3} \cdot \mathrm{cm} / \mathrm{cm}^{2} \cdot \mathrm{s} \cdot \mathrm{cmHg}\right)\right]$

\begin{tabular}{|c|c|c|c|}
\hline $\mathrm{O}_{2}$ & $\mathrm{~N}_{2}$ & $\mathrm{CO}_{2}$ & $\mathrm{~N}_{2} \mathrm{O}$ \\
\hline 0.12 & 0.02 & 1.49 & 1.36 \\
\hline
\end{tabular}

カフを膨張させる気体が、(i)通常の空気の場合と、(ii) 空気と炭酸ガスの混合気体の場合についてシミュレーシ ヨンした。(ii)については、炭酸ガスがカフ内から排出す ることにより、笑気ガスの進入によるカフ内圧の上昇分 を代償させることを目的とした。カフ膜のガス透過係数、 面積、および肺側の炭酸ガス分圧を基に炭酸ガス濃度の 概略值を算出する。

笑気はカフ内から口側・肺側の両方向に対して接し、 炭酸ガスは肺側とカフ内の夕接しているため膜の面積比 は笑気: 炭酸ガス $=2: 1$ となる。気体透過係数の比は、 笑気 : 炭酸ガス $=1.36: 1.49$ である。進入する笑気を補 償するには炭酸ガスの気体透過量を笑気と等しくする。 膜面積の比と気体透過係数の比から算出すると、肺側と カフ内の笑気と炭酸ガスの分圧差を笑気 : 炭酸ガス $=$ $2.98: 1.36$ となるようにする。肺側の笑気分圧は $36 \mathrm{cmHg}$ なので必要な炭酸ガス分圧の差は $16.4 \mathrm{cmHg}$ となる。肺 側の炭酸ガス分圧は $4 \mathrm{cmHg}$ なのでカフ内に必要な炭酸 ガス分圧は $20.4 \mathrm{cmHg}$ である。これより炭酸ガス濃度の 概略值は約 $27 \%$ となる。この值を基に最適值はシミュレ ーションによって定める。 


\section{RESULTS}

III-A.Partial pressures (inflation with air)

Fig.5 に空気でカフを膨張させた場合のカフ内圧、各ガ ス成分の分圧の変化を示す。初期内圧を $2 \mathrm{cmHg}$ とした。 圧は絶対圧で示してある。

カフ内圧は開始後約 10 時間にかけて急速に約 $20 \mathrm{cmHg}$ 上昇している。これはカフ内圧の適正值(大気圧 +2 ～ $5 \mathrm{cmHg}$ )より大幅に上回っている。

笑気分圧はカフ内圧と概ね平行して上昇しているため、 カフ内圧の上昇の主因であることが明らかである。また、 笑気の進入は挿管中持続するが、口側に排出される量と 同じになるとカフ内圧への寄与はなくなる。

室素ガスと酸素ガスの分圧変化は緩やかで、かつ相反 しているためカフ内圧への影響は小さい。麻酔ガスの組 成を変えれば当然酸素分圧も変化するが、その影響はや はり無視できる。
炭酸ガス分圧はわずかに上昇が認められるが、これは 肺側の呼気ガス中の炭酸ガスの進入であり、カフ内圧へ 寄与は少ない。

III-B. Partial pressures(compensated with $\mathrm{CO}_{2}$ ) カフを空気と炭酸ガスの混合気体 $\left(\mathrm{CO}_{2} 30 \%\right)$ で膨張さ せた場合のカフ内圧の変化と、各ガス成分の分圧変化を Fig.6 に示す。麻酔ガスの組成は前記と同じである。初期 内圧は $3 \mathrm{cmHg}$ とした。

カフ内圧は開始から約 15 時間後まで適正範囲内に維 持されている。初期にわずかな減少が見られるが、これ は適正範囲内であって臨床上問題になる圧変化ではない。 笑気分圧は前記とほぼ同様に増加する。

炭酸ガス分圧は概ね笑気と相反して減少し、笑気によ るカフ内圧の上昇を抑えていることが明示されている。

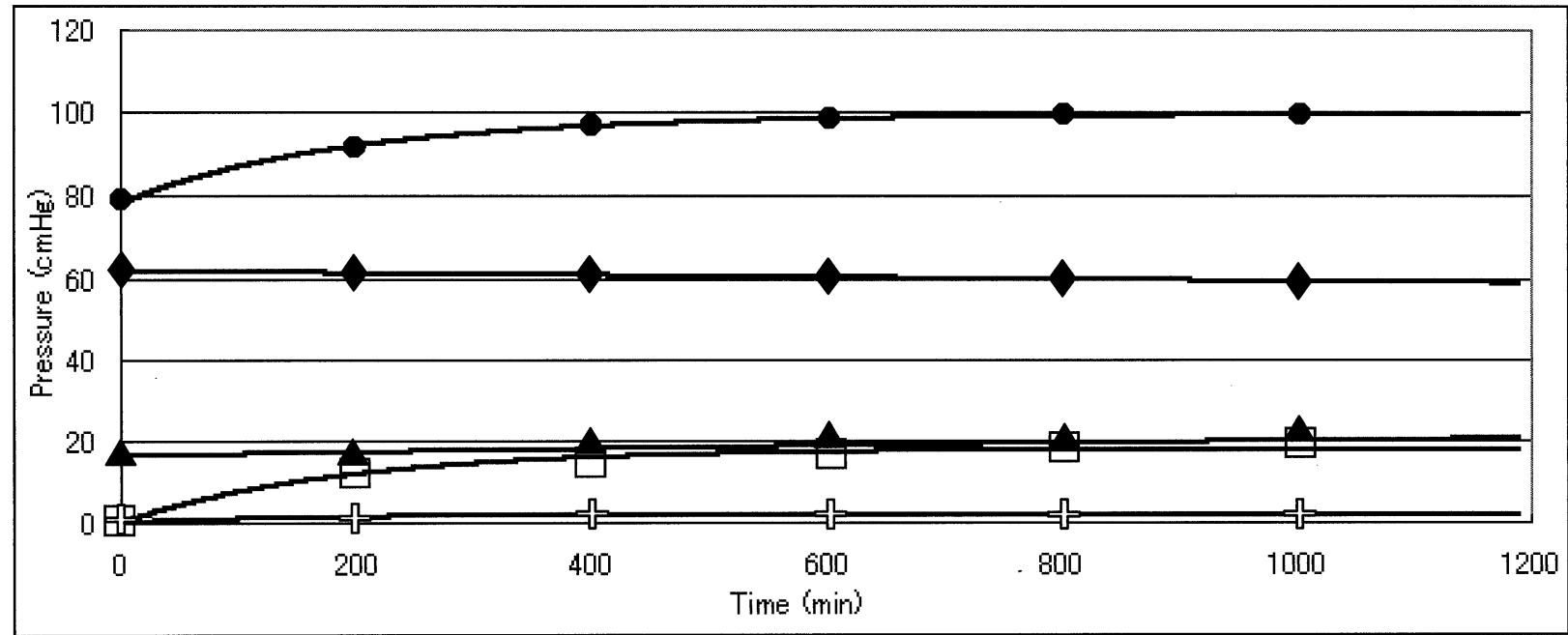

Fig.5. Partial pressure changes in case of standard gas mixture. ( $\bullet$ :total, $\bullet: \mathrm{N}_{2}, \boldsymbol{\Delta}: \mathrm{O}_{2}, \square: \mathrm{N}_{2} \mathrm{O}$, \& : $\mathrm{CO}_{2}$ )

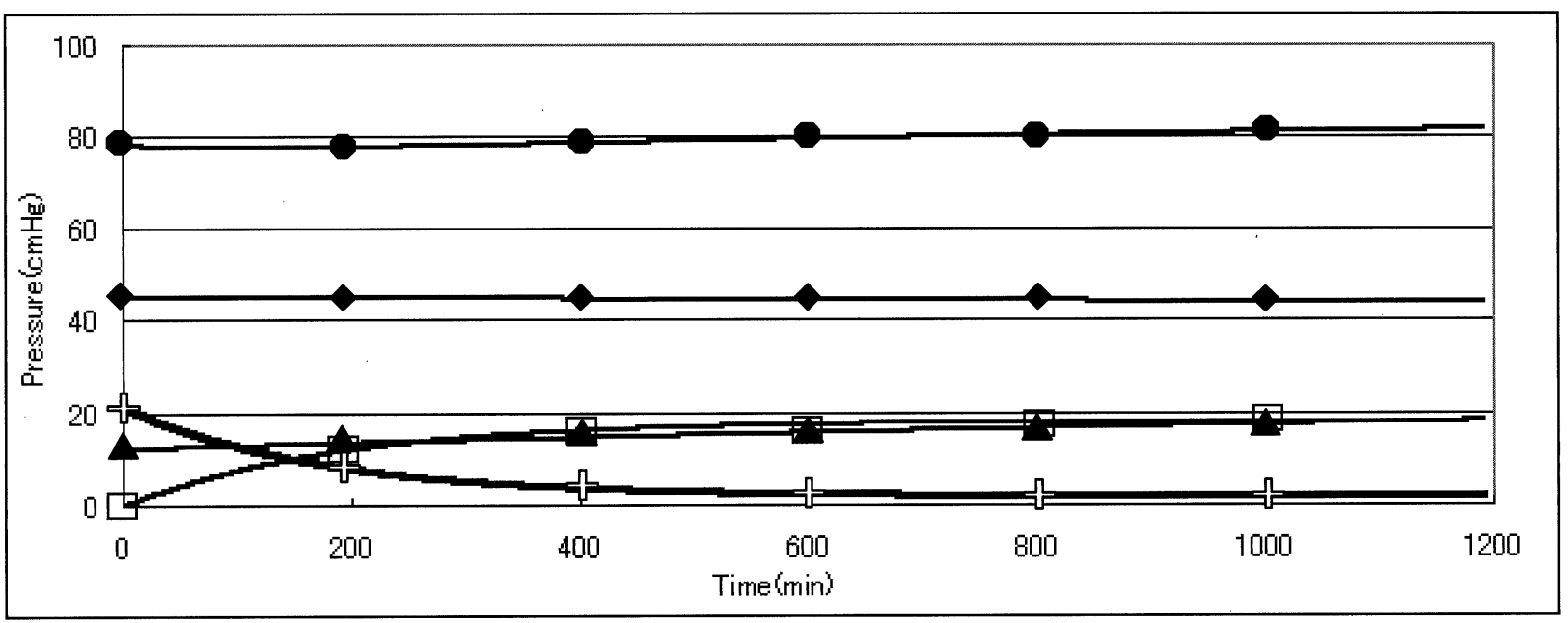

Fig.6. Partial pressure changes in case with $\mathrm{CO}_{2}$. $\bullet$ :total, $\left.\bullet: \mathrm{N}_{2}, \boldsymbol{\Delta}: \mathrm{O}_{2}, \square: \mathrm{N}_{2} \mathrm{O}, \&: \mathrm{CO}_{2}\right)$ 
炭酸ガスのカフ内容量は限られているため、排出は初 期に限られ、約 10 時間後には肺側の炭酸ガス分圧と口側 との間で平衡する。

窒素ガスと酸素ガスの分圧の変化は前記と同様に緩や かでカフ内圧への影響は少ない。

\section{DISCUSSION}

吸入麻酔を用いた手術中、カフ内圧は麻酔医が圧を見 ながら適宜調節している。この手間と気管粘膜の傷害の 対策として現在まで、笑気を透過しにくい素材を使用す る (バリアーカフ)、パイロットバルーンにリザーバをつ ける、圧を一定に保つ装置を使用する、3 といった対策 案がいくつか報告されている。しかし、バリアーカフは 膜材料が硬くなってしまい気管粘膜への攻撃性が高くな る、リザーバーを使用する場合は大きなパイロットバル ーンを必要とする、圧を一定にする装置は高価で場所を 取る、といった欠点がある。安全でほぼ無害である扱い やすい炭酸ガスを添加することによってカフ内圧の上昇 を抑えうる可能性があることを示した。

高分子膜を介してのガス移動は、数理解析の格好の対 象であり、膜を介したガス移動の解析やそのシミュレー ションに関する報告は多い。4,5 気体の移動をシミュレ ーションすることは各ガスの動きをグラフィカルに捉え ることができるので、カフ内圧上昇の対策を考える上で 非常に有用な手段となった。本稿で示したシミュレー ションの結果は 1 つの気管内チューブを対象としたもの である。気管内チューブの種類やメーカーによって、カ フ膜材質、膜厚、面積、体積などのパラメータが異なる ので、本稿で述べた結果がそのまま臨床に適用できるわ けではない。実際の気管内チューブを用いた実験室的検 討、すなわち、カフを笑気・酸素混合気に曝したときの カフ内圧の変動を観測しながら、炭酸ガス濃度の適值を 確認する必要があることはいうまでもない。しかし、シ ミュレーションによって、笑気の進入による圧上昇を炭 酸ガスの排出によって代償させる手法が 1 つの解決策に なりうることを示した。
カフ内圧の変動に関しては笑気を使用する手術中のみ でなく、ICUなど高濃度の酸素を使用し、さらに数十時 間といった長時間使用する人工呼吸中においても臨床上 問題となることがある。このような場合のカフ内ガス組 成の検討などに、本稿で示した方法は有用な手段を提供 する。さらに検討を進めたい。

炭酸ガスがカフ内で有意の分圧を維持するためには相 当する量がカフ内に存在しなければならない。シミュレ ーションに使用した標準的な気管内チューブのカフ容量 は $8 \mathrm{~cm}^{3}$ 程度である。現在使用されている気管内チューブ には、カフ内圧を下げるため、気管壁に接触する面積を 大きくしてシーリング効果を確保する低圧大容量カフと 呼ばれるチューブがある。容量が大きいため、炭酸ガス 分圧の維持が容易になる可能性がある。今後、検討した い。

肺側には麻酔ガスとともに湿度 $100 \%$ の呼気が存在す る。水蒸気は気体に比べて粘性が高く、高分子膜に対す る作用はよく分かっていない。炭酸ガスその他のガスと の相互作用（溶解等）を含めて、実験的な検討結果をシ ミュレーションに反映させたい。

\section{CONCLUSION}

カフを膨らませる空気に炭酸ガスを混ぜることでカフ 内圧の上昇を防止できる可能性があることがシミュレー ションによって確認された。

\section{REFERENCES}

1 T.Sato.Anesthesiology:28,74-79(1979).

2 T.Nakagawa.Membrane.Sangyo Tosho.(1992).P96.

3 Y.Shimizu,A.Namiki,T.Takahashi.Clinical

Anaesthesia 61653 - 1655,(1982).

${ }^{4}$ Mehta S. Br J Anaesth 53.1227-1231,(1981).

${ }^{5}$ Chandler M. Anaesthesia 41.287-293,(1986)

SAS Award (Prize of Silver) was given to this paper presented as Poster Presentation at the 2003 SAS Intelligent Symposium. 